\title{
Prairie Sandreed \\ (Calamovilfa longifolia): \\ Water Infiltration and Use
}

\section{J. KRISTIAN AASE AND J. ROSS WIGHT}

Highlight: Prairie sandreed (Calamovilfa longifolia) near Sidney, Mont., grows on rangeland in colonies ranging from 1 to $8 \mathrm{~m}$ in diameter. There were small differences in soil texture between prairie sandreed colonies and surrounding vegetation. Increased plant growth and residue accounted for higher water infiltration rates within the prairie sandreed colonies than on surrounding vegetation. Prairie sandreed used slightly more water, but the water-use efficiency was nearly twice that of the surrounding vegetation.

Prairie sandreed (Calamovilfa longifolia) grows on sandy prairie soils throughout the north and central Great Plains. It is a tall, coarse, tough, perennial, warm-season grass with large, spreading rhizomes. Near Sidney, Mont., it grows on soils of medium to coarse texture in colonies ranging from about 1 $\mathrm{m}$ to $8 \mathrm{~m}$ in diameter. It grows in nearly pure stands, resulting in distinct boundaries between prairie sandreed colonies and surrounding vegetation.

Prairie sandreed is a high producer and can be an important forage species. It is utilized extensively in summer and winter grazing systems (Forest Service, 1937; Phillips Petroleum Company, 1963;

The authors are soil scientist and range scientist, U. S. Department of Agriculture, Sidney, Montana.

The research is a contribution from the Northern Plains Branch, Soil and Water Conservation Research Division, Agricultural Research Service, U. S. Dep. Agr., in cooperation with the Montana Agricultural Experiment Station. (Journal Series No. 330.)

Manuscript received February 9, 1972.
Welch, 1968). On the site studied, prairie sandreed disappears under high grazing intensities and is considered a "decreaser" under the Soil Conservation Service range condition classification system (Soil Conservation Service, 1971b).

Because of the distinct growth pattern of prairie sandreed, we investigated possible differences from the adjacent mixed prairie vegetation, particularly in soil profile and texture and water infiltration and water-use patterns.

\section{Study Area and Procedure}

The study area was located $2.5 \mathrm{~km}$ northwest of Sidney, Mont. $\left(47.45^{\circ} \mathrm{N}\right.$ and $104.10^{\circ} \mathrm{W}$ ), on a $2 \%$ east slope of rolling glacial-till upland. Site elevation was $600 \mathrm{~m}$. The climate is continental, and annual precipitation averages $33 \mathrm{~cm}$ with $80 \%$ falling during the growing season (April-September).

The soil (Williams loam) is classified as fine-loamy, mixed family of Typic Argiborolls formed on a thin loamy mantle over glacial till. The soil is well drained with no evidence of salt or alkali. 
The site is classified according to the Soil Conservation Service System of Range Classification as a sandy glaciated plains $25-43 \mathrm{~cm}$ precipitation zone range site (Soil Conservation Service, 1971a). Species composition and percent basal cover as determined by the point method are shown in Table 1.

Prairie sandreed colonies, about $6 \mathrm{~m}$ in diameter, were selected for study. A pit was dug across a prairie sandreed colony into the surrounding mixed prairie vegetation. Soil Conservation Service personnel classified and described the soil, and samples for particle size analyses were taken from the walls of the pit. Soil samples were also taken from 26 prairie sandreed colonies and adjacent vegetation within a $32-\mathrm{km}$ radius of the study site for particle size analyses. Soil samples were taken from the following depth increments: 0 to $2.5 \mathrm{~cm}, 2.5$ to $5.0 \mathrm{~cm}$, 5.0 to $7.5 \mathrm{~cm}, 7.5$ to $10.0 \mathrm{~cm}, 19.0$ to $21.0 \mathrm{~cm}$, and 29.0 to $31.0 \mathrm{~cm}$. Particle size was determined by the hydrometer method. Access tubes for soil water determinations by the neutron scattering method were installed to a depth of 125 $\mathrm{cm}$ in the middle of and adjacent to three selected colonies. Livestock was excluded from these colonies. Soil water at 15-, 45-, 75-, and 105-cm depths was determined 20 times from May 1968 to July 1969.

A truck-mounted infiltrometer (Bertrand and Parr, 1961; Dixon and Peterson, 1964) was used to study water infiltration characteristics. Spray nozzles operating at about $0.6 \mathrm{~kg} / \mathrm{cm}^{2}$ pressure, $2.7 \mathrm{~m}$ from the ground surface and rotating at about $10 \mathrm{rpm}$ on a $30-\mathrm{cm}$ diameter, were used. Simulated rainfall intensities ranged from 12 to $37 \mathrm{~cm} / \mathrm{hr}$ and were applied from 30 to 60 minutes to 117 - by $117-\mathrm{cm}$ plots.

Before infiltration runs were made, replicated surface treatments inside and outside the prairie sandreed colonies were imposed as follows: (1) undisturbed, (2) vegetation clipped to soil surface, (3) surface $3 \mathrm{~cm}$ of soil removed, (4) a 4-cm-thick layer of wheat straw on each of the above treatments, and (5) no straw applied. Paired infiltration runs inside and adjacent to the prairie sandreed colonies were made in 1968, 1969, and 1971. Antecedent soil water in the top $30 \mathrm{~cm}$ of soil was determined.

Daily precipitation records were obtained from a U.S. Weather Bureau Class A raingage located about $0.8 \mathrm{~km}$ from the study area.

Dry matter production was determined by clipping three $0.5-$ by $2.0-\mathrm{m}$ areas at ground level inside and outside three prairie sandreed colonies. Water-use efficiency determinations were based on above ground dry matter production and soil water use plus precipitation from May 27 to harvest.

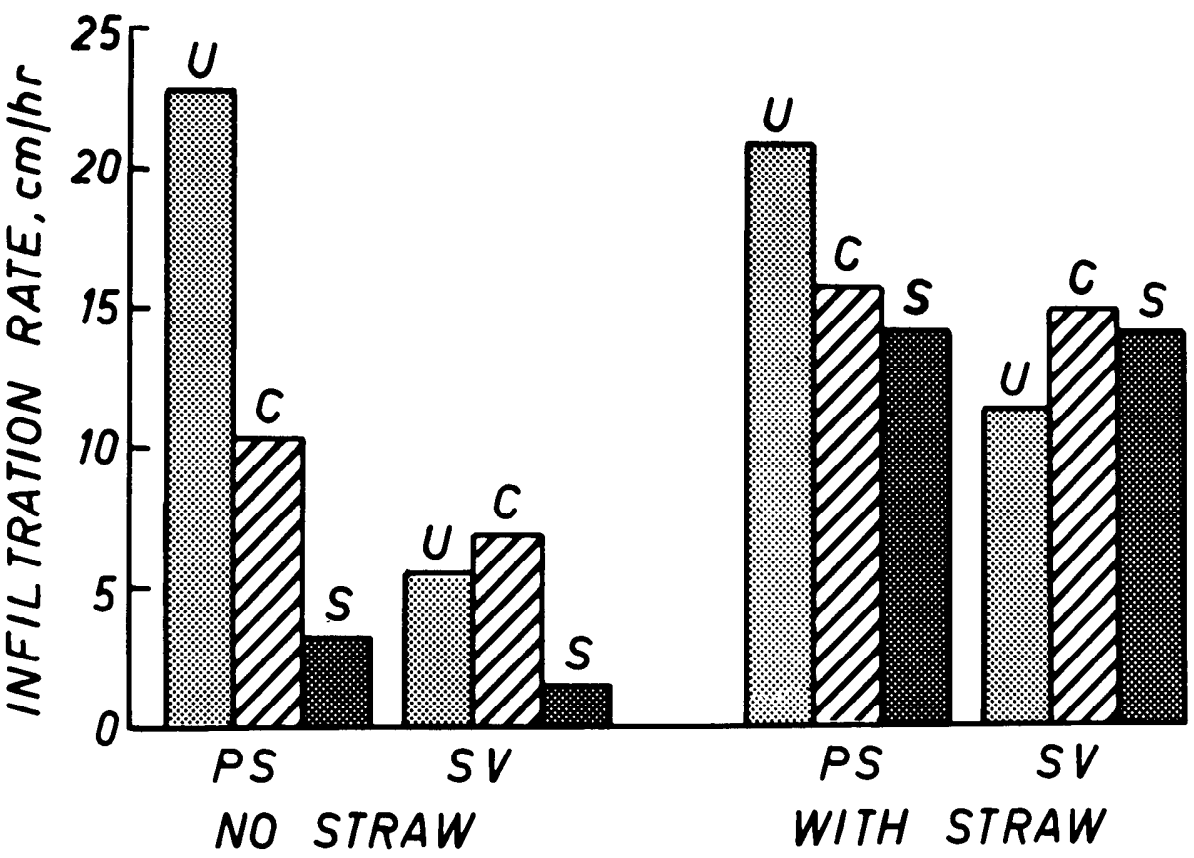

Fig. 1. Infiltration rates on prairie sandreed (PS) and surrounding vegetation (SV). Treatments are undisturbed $(U)$, vegetation clipped at ground surface $(C)$, and surface $3 \mathrm{~cm}$ of soil removed (S).

\section{Results and Discussion}

Results of infiltration runs are summarized in Figure 1. Antecedent soil water had no measurable effect on the relative infiltration rates. Infiltration rates on undisturbed prairie sandreed were significantly higher and averaged about four times those on undisturbed surrounding vegetation. When vegetation in infiltrometer plots inside and outside prairie sandreed colonies was clipped at ground surface, soil under prairie sand- reed again showed a significantly $(P=0.10)$ higher intake rate than soil under adjacent vegetation.

When the top laycr of soil $(2$ to $3 \mathrm{~cm}$ including any organic matter) was removed, infiltration was greatly reduced on both prairie sandreed and surrounding vegetation.

Additions of $4-\mathrm{cm}$ layers of straw generally increased infiltration on sandreed colonies and more than doubled infiltration rates on surrounding vegetation. There were no significant dif-
Table 1. Basal cover and composition (C) in percent, based on point frame measurements, and dry matter production $(\mathrm{kg} / \mathrm{ha})$, water use (WU) $(\mathrm{cm})$, and water-use efficiency $(W U E)\left(\mathrm{kg} / \mathrm{ha} / \mathrm{cm}^{*}\right)$ within and adjacent to prairie sandreed colonies during May 23 to September 3, 1968.

$\frac{\text { Prairie sandreed colony }}{\text { Cover C Matter WU WUE Cover C Matter WU WUE }}$

Prairie sandreed

$\begin{array}{lllllll}\text { (Calamovilfa longifolia) } & 2.3 & 66 & 1313 & 0.0 & 0 & 1\end{array}$

Western wheatgrass

(Agropyron smithii)

Blue grama

(Bouteloua gracilis)

Prairie junegrass

(Koeleria cristata)

Needleand thread

(Stipa comata)

Threadleaf sedge

(Carex filifolia)

Needleleaf sedge

(Carex eleocharis)

Total grasses and sedges

$0.0 \quad 0 \quad 68$

$0.7 \quad 14 \quad 382$

Total forbs

$0.3 \quad 9<1$

$2.8 \quad 56 \quad 68$

$0.0 \quad 0 \quad 4$

$\begin{array}{lll}0.1 & 2 & 27\end{array}$

Fringed sagebrush

(Artemisia frigida)

$0.0 \quad 0 \quad 0$

$\begin{array}{lll}0.3 & 6 & 25\end{array}$

$\begin{array}{lll}0.5 & 14 & 15\end{array}$

$\begin{array}{lll}0.9 & 18 \quad 39\end{array}$

$\begin{array}{lll}0.4 & 11 \quad 11\end{array}$

$3.5 \quad 100 \quad 1411$

$0.0 \quad 0 \quad 44$

Total vegetation

$0.0 \quad 0 \quad 42$

$\begin{array}{lll}4.8 & 96 & 586\end{array}$

$0.1 \quad 2 \quad 39$

$0.0 \quad 0 \quad 0$

$\begin{array}{lll}0.1 & 2 & 117\end{array}$

* Kg dry matter per ha per $\mathrm{cm}$ water used. 


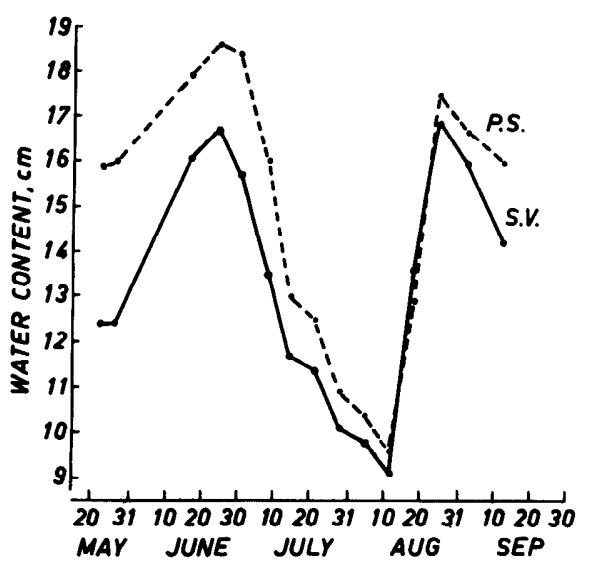

Fig. 2. Soil water content under prairie sandreed (PS) and adjacent vegetation (SV) during 1968 season.

ferences among straw treatments, except undisturbed prairie sandreed without straw was higher than undisturbed surrounding vegetation with straw.

According to profile descriptions, sand content in the $\mathrm{Al}$ and clay content in the $B$ horizon were higher under prairie sandreed than under adjacent mixed vegetation, indicating eluviation under prairie sandreed. Statistically, the only significant difference $(P=0.10)$ in texture was a higher clay content in the $2.5-$ to $5.0-\mathrm{cm}$ increment under prairie sandreed. Soil texture of all sampled colonies ranged from sandy loam to loam.

It appears that the greater infiltration rate in prairie sandreed colonies has one main cause: the vigorous growth and resultant residue of prairie sandreed intercepts rain, and raindrops reach the soil surface with far less energy than they do on ground with less cover, causing less sealing of the soil surface. Moldenhauer and Long (1964) arrived at the same conclusion by placing screens over the soil surface to break the impact of the raindrops. They also discussed the effect of soil texture on infiltration; infiltration rates were higher on coarse- than on finetextured soils. Soil texture may play a secondary role in influencing infiltration on prairie sandreed colonies as indicated from the small textural differences between them and surrounding vegetation.

Higher soil water content under prairie sandreed colonies in the spring of 1968 and 1969 reflected higher infiltration and later initiation of growth by prairie sandrced than by surrounding vegetation. Snow catch in prairie sandreed was much greater than in surrounding vegetation. Water use by prairie sandreed (Fig. 2) compared to surrounding vegetation increased in June, and by the end of July there was little difference in soil water content inside and outside prairie sandreed colonies. From the end of July to August 26 there was no difference in water use between the two vegetation types. However, from August 26 to September 13 , surrounding vegetation used more water than prairie sandreed as a result of the initiation of new tillers following unseasonably high rains in August 1968. Most water use for this period was confined to the top $45 \mathrm{~cm}$ of soil.

Total water use during growing season was slightly higher by prairie sandreed than by surrounding vegetation. Dry matter production of prairie sandreed was twice that of the surrounding vegetation; water-use efficiency, 1.8 times (Table 1).
Results of this study demonstrate the important role both living plants and litter play in the water budget of a plant community. Snow catch and water infiltration were increased by increasing plant cover. Thus, determination of optimum grazing intensities should include not only the effects of foliage removal on the growth and survival of plants but also the maintenance of an adequate plant cover.

\section{Literature Cited}

Bertrand, A.R., and J.F. Parr. 1961. Design and construction of the Purdue sprinkling infiltrometer. Purdue Agr. Exp. Sta. Res. Bull. 723

Dixon, R.M., and A.E. Peterson. 1964. Construction and operation of a modified spray infiltrometer and a flood infiltrometer. Wisconsin Agr. Exp. Sta. Res. Rep. 15.

Forest Service. 1937. Range plant handbook. U.S. Government Printing Office, Washington, D.C.

Moldenhauer, W.C., and D.C. Long. 1964. Influence of rainfall energy on soil loss and infiltration rates: I. Effect over a range of texture. Soil Sci. Soc. Amer. Proc. 28:813-817.

Phillips Petroleum Company. 1963. Pasturc and range plants. Phillips Petroleum Company, Bartlesville, Oklahoma. 176 p.

Soil Conservation Service. 1971̣. Range site criteria. Technical guide, section II-E-3 (Soil Conserv. Serv., Bozeman, Mont.) 2 p.

Soil Conservation Service. 1971b. Technician's guide to range sites, condition classes and recommended stocking rates in the Soil Conservation Districts of the Glaciated Plains of Montana, 10-14" precipitation zone Technical guide, section III-D-1. (Soil Conserv. Serv., Bozeman, Mont.) $2 \mathrm{p}$.

Welch, Tommy G. 1968. Carbohydrate reserves of sand reedgrass under different grazing intensities. J. Range Manage. 21:216-220.

\title{
1973 Summer Meeting
}

\section{Fort Lewis College $\bullet$ Durango, Colorado}

\author{
July 18-20, 1973
}

See the April issue of RANGEMAN'S NEWS for complete details. 